\title{
Influence of applied electrical fields on yeast and hyphal growth of Candida albicans
}

\author{
Tanya Crombie, Neil A. R. Gow* and Graham W. Gooday \\ Department of Genetics and Microbiology, Marischal College, University of Aberdeen, Aberdeen AB9 IAS, UK
}

(Received 21 August 1989; revised 16 October 1989; accepted 13 November 1989)

\begin{abstract}
Yeast cells of Candida albicans which had been attached to polylysine-coated microscope slides were induced to form buds or germ tubes in the presence of external electrical fields. The sites of budding and germ tube formation and the growth of germ tubes and hyphal branches were polarized preferentially towards the cathode. Buds were not converted to pseudohyphae or germ tubes by the field and the field had no effect on the positioning of nuclei or septa in the yeast cell or germ tube. Buds were less polarized than germ tubes at any given applied voltage. The polarization of buds reached a peak at an electrical field of $12 \mathrm{mV}$ per cell. Polarization of germ tubes was biphasic, incréasing rapidly with increasing field strengths up to $5 \mathrm{mV}$ per cell, and thèn more slowly in stronger fields. An electrical field was only required for a fraction of the time taken for germ tubes to start to form, so cells retained a memory of experiencing an electrical field which influenced the selection of sites of evagination. Increasing the electrical field delayed the time of germ tube evagination and inhibited the rate of germ tube extension. Unlike previous findings with other filamentous fungi, germ tubes grew unidirectionally towards the cathode for extended periods and did not deviate to a perpendicular orientation. This result suggests that the septal pore of the filamentous form may have high electrical resistance and would act as an effective barrier to solute transport between intercalary compartments.
\end{abstract}

\section{Introduction}

Growing fungal hyphae normally generate an electrical current so that positive charge enters the hyphal tip and exits from the rear (Gow, 1984; Harold et al., 1985; Gow, $1989 a, b)$. A great deal of effort has been spent in trying to establish the functional relationship between the morphological and electrical polarity of these cells (Gow, $1989 \mathrm{~b}$ ). The information obtained to date shows that hyphal growth is invariably accompanied by the generation of an electrical current, but the natural electrical fields of a range of hyphae are somewhat variable. For example, during vegetative growth in Achlya bisexualis (Kropf et al., 1983; Schreurs \& Harold, 1988), Allomyces macrogynus (Youatt et al., 1988) and Neurospora crassa (McGillivray \& Gow, 1987; Takeuchi et al., 1988), and asexual differentiation in Achlya bisexualis (Thiel et al., 1988), hyphae have been described where the endogenous current pattern changed in magnitude or direction without consequence to the rate of tip extension. However, in Achlya bisexualis, where the current has been characterized in most detail, there seems to be a better correlation between the influx of protons (as

Abbreviation: DAPI, 4',6-diaminido-2-phenylindole. opposed to electrical current) and the ability of the hypha to extend (Gow et al., 1984).

Other evidence which suggests that bioelectric phenomena may be important to the organizational processes concerned with the polarity of hyphal growth come from studies where cells are exposed to applied electrical fields (Gow, 1987). For a range of mycelial fungi electrical fields cause orientation of germ tubes, hyphae, branches and rhizoids and polarization of sites of germination (De Vries \& Wessels, 1982; McGillivray \& Gow, 1986; Van Laere, 1988; Youatt et al., 1988). Growth per se does not seem to be adversely affected by electrical fields; rather their effects were directed specifically on those aspects of cell physiology concerned with polarity.

Here we investigate the effect of electrical fields on a dimorphic fungus, Candida albicans. The switch from yeast to hyphal growth represents a transition to a more polarized form of growth since budding occurs predominantly by isotropic wall expansion while germ tube growth is confined mainly to the apex (Staebell \& Soll, 1985). We show that both yeast and hyphal forms are polarized by the electrical fields but that the fields do not induce the yeast-hyphal transition. The effects of the electrical fields on growth, septation and nuclear behaviour are described. 


\section{Methods}

Organism and growth media. Candida albicans (Robin) Berkhout strain 3153A was obtained from the Mycological Reference Laboratory, Colindale, London, UK. The organism was maintained in the yeast form in the defined medium of Lee et al. (1975), modified according to Buffo et al. (1984) and referred to here as Soll's medium (SM). Yeast cultures were grown on agar slants or in shake-flasks in SM at $25^{\circ} \mathrm{C}$ at an initial $\mathrm{pH}$ of $4 \cdot 5$. For experiments in electrical fields this medium was modified to increase its resistivity to $1220 \Omega \mathrm{cm}$ by reducing the concentration of all salts by a factor of 200 and supplementing the medium with sorbitol to restore the original osmolarity of SM. The cells did not grow on sorbitol. The chloride salts $\mathrm{MgCl}_{2}$ and $\mathrm{CaCl}_{2}$ were omitted since their presence resulted in chlorine being generated at the anode. This modified medium is referred to as MSM. These modifications had no measurable effect on specific growth rate of the yeast form at $25^{\circ} \mathrm{C}, \mathrm{pH} 4 \cdot 5$, caused only a $4 \%$ reduction in the efficiency of germ tube formation and a reduction in yield from 2.4 to $2.0 \mathrm{mg} \mathrm{ml}^{-1}$.

Induction of budding and germ tube growth on microscope slides. The general method was as described by Buffo et al. (1984). This method employs changes in external pH to control morphology so that germ tubes are produced when cells are suspended in fresh media at $\mathrm{pH} 6.5$ and buds are formed at $\mathrm{pH}$ 4.5. The inocula for experiments were stationary phase cultures of yeast cells grown in MSM, $25^{\circ} \mathrm{C}$, initial pH 4.5. In previous studies of fungi in electrical fields the specimens were prepared and examined embedded in an agarose gel. $C$. albicans cells are small and require high-power magnification to make accurate measurements with a light microscope. Such measurements proved impossible in gels because of the necessity of a close working distance between specimen and objective lens. A slide-culture technique was therefore devised. A sample of $C$. albicans culture was removed and added as single drops to a microscope slide coated with polylysine. The cells were left for $30 \mathrm{~min}$ to settle and attach and the excess, nonadherent cells were washed off using MSM. This procedure gave a preparation in which the cells were of an appropriate concentration when viewed under the microscope. Polylysine-coated slides were prepared by placing degreased, heat-sterilized microscope slides into a $0.01 \%$ solution of filter-sterilized poly-L-lysine (Sigma) for $20 \mathrm{~min}$, then allowing the slides to dry horizontally in a sterile air-flow cabinet with UV irradiation. In some experiments small, square pieces of microscope slide were prepared to allow individual slides to be sampled at intervals. The slide-cultures were placed in the electrical field apparatus described below. After exposure to the electrical field the slides were removed and fixed in neutral buffered $10 \%(\mathrm{v} / \mathrm{v})$ formalin solution (Sigma). Preparations stained for nuclei and septa as described below were not fixed. Permanent preparations of fixed slides were made using drops of DPX (BDH) as an embedding resin, and using a $2.2 \times 6.4 \mathrm{~cm}$ no. 1 coverslip to sandwich the cells.

Applied electrical field apparatus. A small DNA electrophoresis cell (Bio-Rad; mini-sub cell) was used to apply electrical fields as described by McGillivray \& Gow (1986). Microscope slide preparations were placed in the cell instead of the normal gel tray and MSM was used as a circulating growth medium. Temperature was maintained at $37^{\circ} \mathrm{C} \pm$ $1^{\circ} \mathrm{C}$ by passing the growth medium through a thermostatically controlled circulator and the temperature was checked in situ using a small thermometer probe which could be fed into the electrophoresis cell during running of an experiment. There was no gradient of temperature or $\mathrm{pH}$ along the length of the slide. With the largest electrical fields $\left(57 \mathrm{~V} \mathrm{~cm}^{-1}\right)$ the $\mathrm{pH}$ of the medium tended to fall by 0.2 $\mathrm{pH}$ units $\mathrm{h}^{-1}$. This was offset by the periodic addition of drops of $0 \cdot 1 \mathrm{M}$ KOH.
Calculation of degree of polarization. Slides were examined at $\times 400$, or $\times 1000$ in an Olympus BH2 microscope, using bright-field microscopy. The orientation of the germ tube, bud or site of evagination with respect to the anode-cathode axis was determined using a protractor eyepiece graticule or by measuring from a videoscreen. The anode was designated $0^{\circ}$ and the cathode $180^{\circ}$. Measurements of the cosines of the angles of at least 300 specimens were entered into a computer program and the percentage polarization determined as :

$$
P(\%)=\sum(\cos \theta / n) 100
$$

(McGillivray \& Gow, 1986) where $\theta$ is the angle made by the germ tube, bud or site of evagination to the anode-cathode axis and $n$ is the total number of angles measured. Error bars, where shown, are standard errors of the means of three sets of samples.

Preparation of material for scanning electron microscopy. Some slide preparations were fixed with $1 \%(\mathrm{v} / \mathrm{v})$ glutaraldehyde in phosphate buffer, pH 6.5 , dehydrated in increasing concentrations of ethanol, sputter-coated with $15 \mathrm{~nm}$ of platinum and examined and photographed in a JEOL JSM35CF scanning electron microscope.

Staining of septa and nuclei. Cells were stained on the experimental slides by placing drops of stain containing $0.7 \mathrm{mg} \mathrm{4}$,6-diaminido-2phenylindole $\mathrm{ml}^{-1}$ (DAPI, Sigma), $8 \mu \mathrm{g} \mathrm{ml} \mathrm{m}^{-1}$ Calcofluor white (American Cyanamid Co.) in $33 \%(v / v)$ ethanol on top of the specimens and examining in an Olympus fluorescence microscope. Positions of nuclei and septa relative to the tip were made using a calibrated eyepiece micrometer.

\section{Results}

\section{Cytology of germ tube and bud formation in electrical fields}

Stationary-phase yeast cells were attached to polylysinecoated microscope slides and induced to form germ tubes or buds in electrical fields. Buds were formed when the $\mathrm{pH}$ of the circulating medium (MSM) was at 4.5 whereas germ tubes were formed when the medium was at $\mathrm{pH} 6.5$. The orientations of yeast cells with an obvious ellipsoidal shape were plotted before and after electrical field application (data not shown). No preferential orientation was found with respect to the field vector. Thus cells tethered with polylysine do not rotate in the electrical field and can be regarded as having a random orientation before and after the field is applied. Germ tubes formed at the cathode-facing side of the cell, and once formed continued to extend towards the cathode (Fig. $1 a, b$ ). The appearance of the germ tube, its diameter and tip shape appeared to be normal during growth in the field (Fig. $1 b)$. In controls the germ tube was often bent or curved (Fig. 1c), unlike germ tubes growing in an electrical field, which were usually straight (Fig. $1 a$ ). Branches were rare for cells growing in this medium, but a few were seen in germlings after $7 \mathrm{~h}$ growth with or without the field (Fig. $1 b$ ). The site of branch formation was also polarized preferentially at the cathodic side of the hypha. In older cells multiple germ tubes were formed, all on the cathodic end of the parent cell (Fig. $2 b$ ). These results imply that the site of germ tube formation is not 

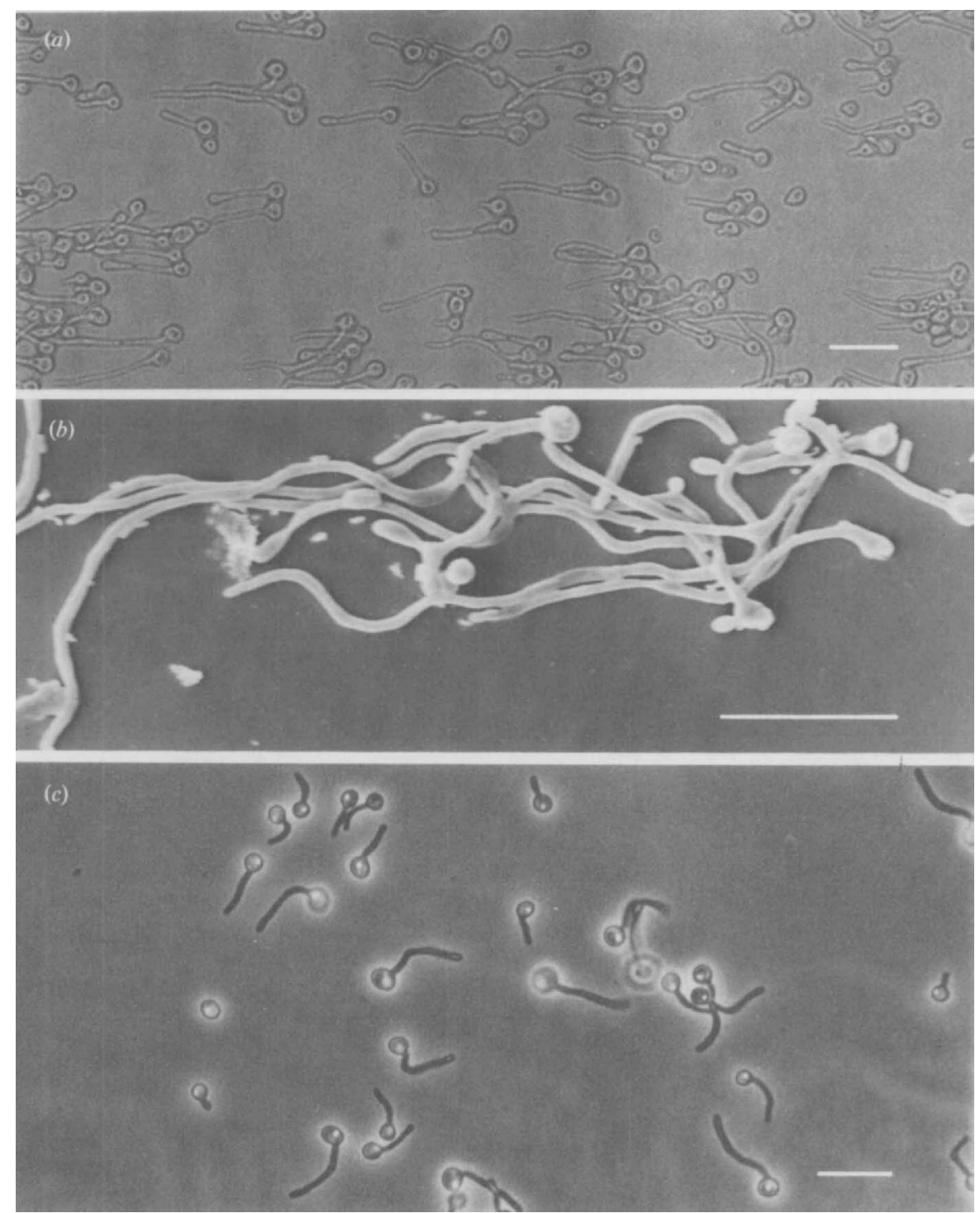

Fig. 1. Germ tube formation and growth of $C$. albicans in an electrical field of $28.5 \mathrm{mV}$ per cell $(a)$ or $20 \mathrm{mV}$ per cell $(b)$ and in a control experiment in the absence of any field $(c)$. In $(a)$ and $(b)$ the cathode is on the left of the picture. Cultures were grown on polylysinecoated microscope slides for $7 \mathrm{~h}(a, c)$ or $24 \mathrm{~h}$ for the scanning electron micrograph $(b)$. Bars represent $20 \mu \mathrm{m}$.

irreversibly predetermined since the electrical field causes an overriding propensity to form a germ tube at one side of the cell. After germ tube formation had occurred reversal of the electrical field caused tips to bend through $180^{\circ}$ until they again grew towards the cathode (Fig. 2c).

Buds also formed on the cathode-facing side of cells (Fig. 2a). A few buds were elongated in appearance but the polarizing influence of the electrical field did not cause the conversion of buds to germ tubes (Fig. 2a). After $7 \mathrm{~h}$ buds were less polarized than germ tubes for all applied fields. This period of time was sufficient for several rounds of bud formation. It is possible that secondary buds are necessarily less polarized than the first buds formed in fields because the first buds displace secondary-ones from the cathodic pole of the cell.

\section{Effects on nuclear and septal positioning}

A series of experiments was carried out to determine the cytological effects of growth in an electrical field. Cells were again grown on polylysine-coated slides; nuclei and septa were visualized by staining with DAPI or Calcofluor, respectively. The position of nuclei in parent 

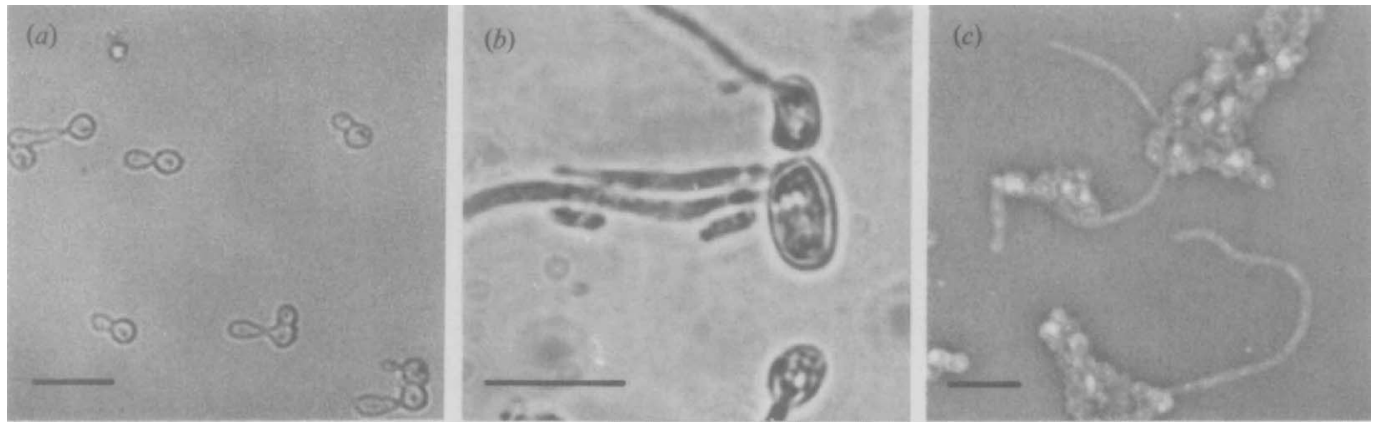

Fig. 2. Bud formation $(a)$, multiple germ tube formation $(b)$, and reorientation of germ tubes after reversal of electrical field $(c)$. In each case the cathode is on the left; the electrical field was $20 \mathrm{mV}$ per cell $(a)$ or $28.5 \mathrm{mV}$ per cell $(b, c)$. The scale bar represents $20 \mu \mathrm{m}$ in $(a)$ and $(c)$ and $1 \mu \mathrm{m}$ in $(b)$.

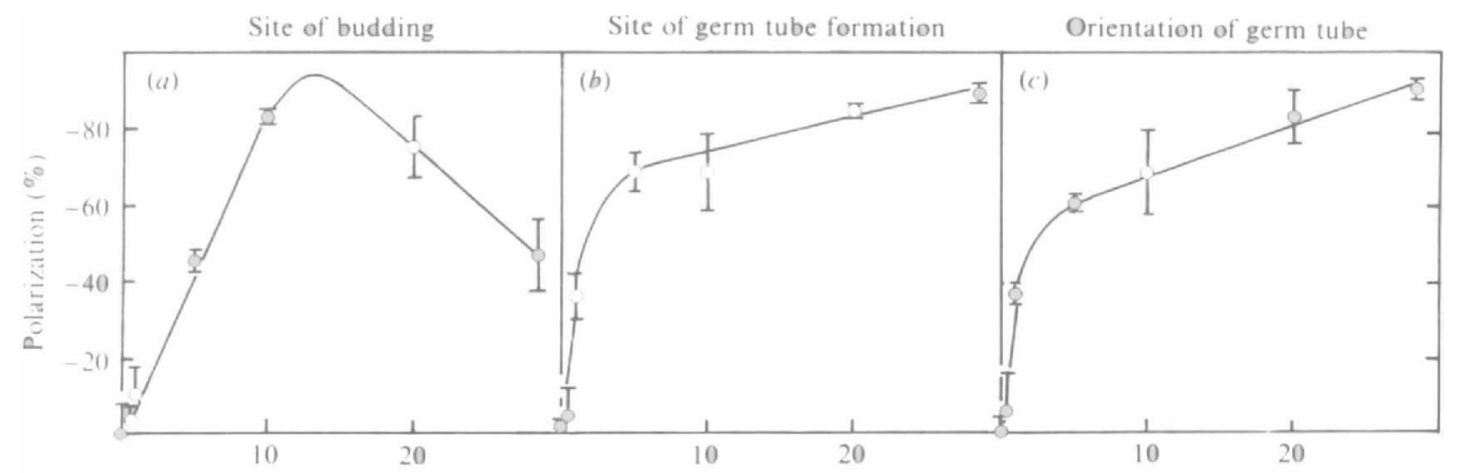

Electrical field ( $\mathrm{mV}$ per cell)

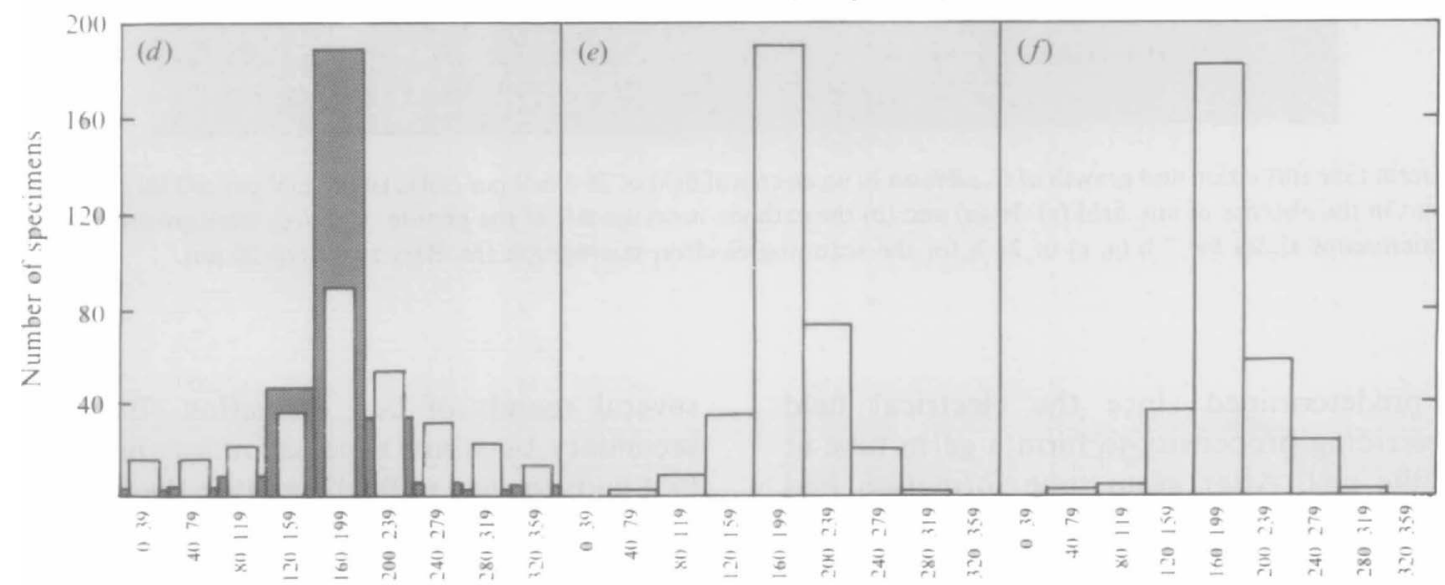

Angle $(\theta)$ with respect to anode cathode axis

Fig. 3. Polarization of budding (a), the site of germ tube formation $(b)$ and the germ tube apex $(c)$ in electrical fields of varying strength. The histograms show the angular distribution of the orientations of buds $(d)$, sites of germ tube outgrowth $(e)$ or germ tube tips $(f)$ for fields of $28.5 \mathrm{mV}$ per cell (blank columns) and for buds in a field of $10 \mathrm{mV}$ per cell (shaded columns in $d$ ). In the histograms the cathode is at $180^{\circ}$ and the anode at $0^{\circ}$. All measurements were made after $7 \mathrm{~h}$ exposure to fields. The error bars are standard errors of the means of three samples, each sample of 100 cells. 
yeast cells was determined as being central or being displaced to the anodic or cathodic ends of the cells. For controls nuclei were scored as being to the right or left of centre as viewed through the microscope. Yeast cells were exposed to an electric field of $20 \mathrm{mV}$ per cell $\left(40 \mathrm{~V} \mathrm{~cm}^{-1}\right)$ for $150 \mathrm{~min}$ or incubated for the same time in the absence of a field. There was no significant difference in the position of the nuclei in the controls and the field-exposed cells. Nuclei had a central position in one-third of cells and a more peripheral position in twothirds of the cells. In the electrical field, as many nuclei were found at the anodic end of the cell as at the cathodic end. In an electrical field of $20 \mathrm{mV}$ cell per cell the tip to nucleus distance of $9 \mathrm{~h}$ germ tubes was $10.5 \pm 1.3 \mu \mathrm{m}$ (SE of three means of 50 cells) compared to $12.3 \pm 0.5 \mu \mathrm{m}$ in controls. The mean tip to primary septum distance of the same cells was $21.4 \pm 0.8 \mu \mathrm{m}$ (again SE of 3 means of 50 cells) compared to a mean of $22.4 \pm 0.6 \mu \mathrm{m}$ for controls. The electrical field therefore had no measureable effect on the positioning of the nucleus or the septum.

\section{Directional growth of cells in electrical fields}

Stationary-phase cells were inoculated onto polylysinecoated slides and induced to growth by budding or germ tube formation in fresh media at $\mathrm{pH} 4.5$ and 6.5, respectively. These slide-cultures were exposed to electrical fields of between 0 and $57 \mathrm{~V} \mathrm{~cm}^{-1}$ (equivalent to 0 $28.5 \mathrm{mV}$ per cell assuming a mean yeast cell diameter of 7 $\mu \mathrm{m})$. Polarization of the sites of budding, germ tube production and germ tube growth was determined. For buds, maximum polarization appeared to occur around 10-13 mV per cell (Fig. 3a). Stronger electrical fields were less effective in polarizing the direction of growth of cells. Possible reasons for this result are discussed below. Experiments applying electrical fields to $N$. crassa showed that hyphae became aligned perpendicularly to strong fields (McGillivray \& Gow, 1986). A change to perpendicular growth causes a reduction in the polarization value measured. However this phenomenon cannot explain the reduction in polarization seen here since the angular distribution function for buds at the strongest electrical field (Fig. 3d) still showed a normal distribution with the modal value corresponding to growth towards the cathode.

Polarization of the site of germ tube formation and the growth of the germ tube once it had formed showed very similar responses to fields of differing strength (Fig. $3 b$, $c, e, f)$. The response was biphasic, showing an initial marked increase in polarization in fields up to $5 \mathrm{mV}$ per cell, followed by a gradually increasing polarization in fields above this value. Maximal values for polarization

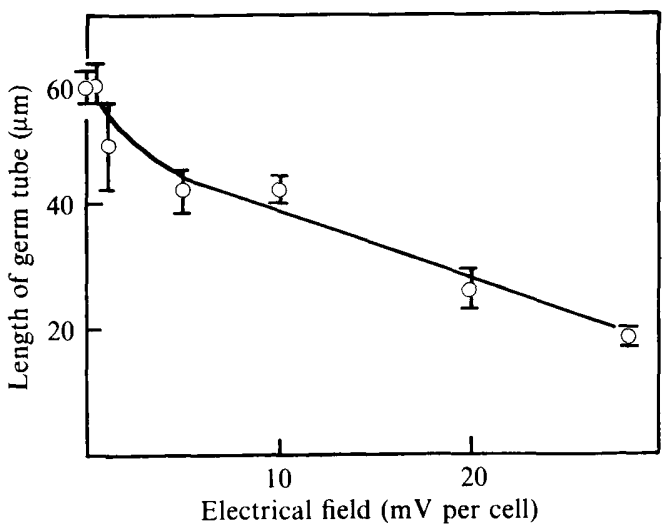

Fig. 4. Mean germ tube length after $7 \mathrm{~h}$ in electrical fields of different strength. The error bars are standard errors of the means of three samples of 100 germ tubes.

were around $90 \%$; however, if cells were scored simply as if they were oriented to the cathode or anode and the precise angle of each germ tube ignored, almost $100 \%$ of the cells become aligned towards the cathode in fields at or greater than $20 \mathrm{mV}$ per cell.

\section{Kinetics of growth in electrical fields}

Electrical fields inhibited germ tube extension(Fig. 4) and caused germ tube formation to be delayed (see Fig. 5), but growth still occurred even at the highest field strengths. When germ tubes were left in a field for $24 \mathrm{~h}$ hyphae continued to grow towards the cathode and did not deviate towards a perpendicular orientation as found with other filamentous fungi (McGillivray \& Gow, 1986).

Yeast cells were exposed to electrical fields for varying periods of time then allowed to form germ tubes in the absence of an electrical field (Fig. 5). In a strong field of $28.5 \mathrm{mV}$ per cell, germ tubes did not start to form until 90 min yet cells which had been exposed to the field for only 30 min were significantly polarized when they eventually formed germ tubes. The cells must therefore retain a memory of the polarizing influence of the electrical field.

In weaker fields the cells were not significantly polarized unless they were in the field for a longer time (Fig. 5) and in general the weaker the field the longer a cell had to be exposed to it to become polarized significantly. For example, for a field of $28.5 \mathrm{mV}$ per cell significant polarization of germ tubes was achieved if the slide-cultures were exposed to the field for only $1 \mathrm{~h}$ while in a field of $1 \mathrm{mV}$ per cell an exposure of $2.5 \mathrm{~h}$ was necessary for significant polarization. 


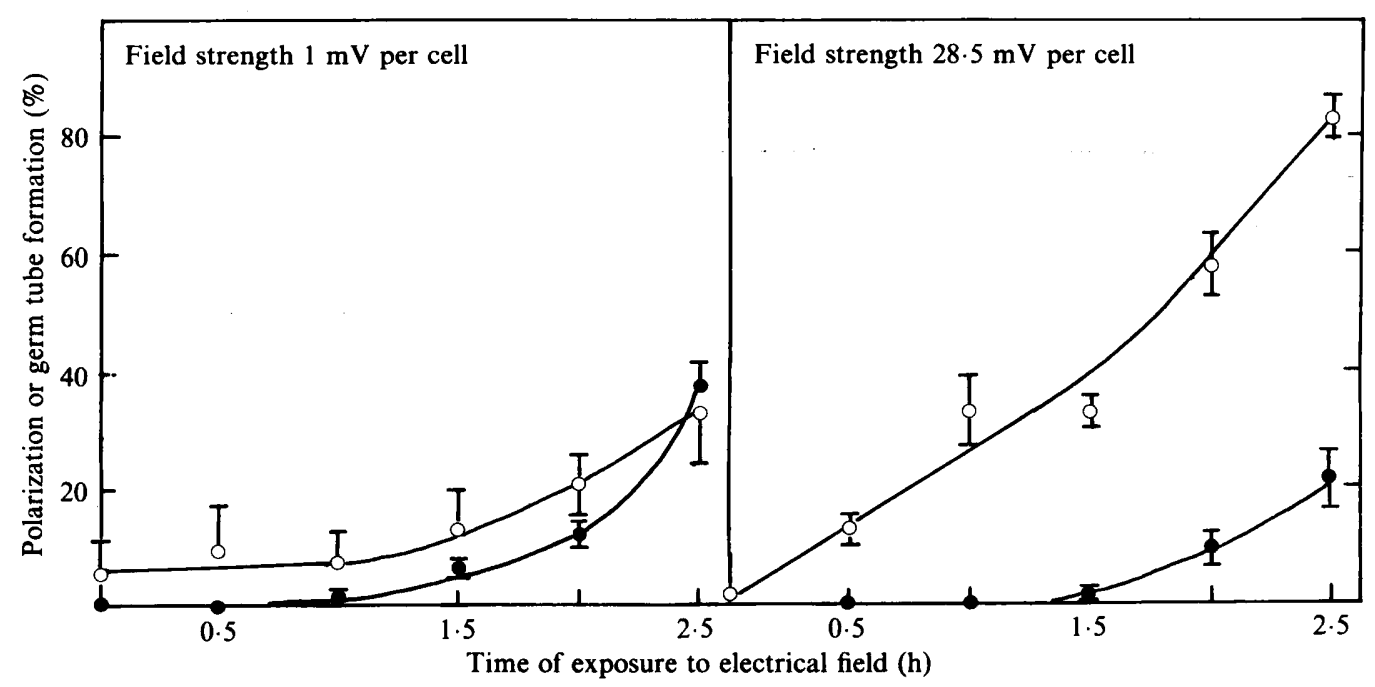

Fig. 5. Effect of electrical field strength on rate of formation of germ tubes $(O)$ and their orientation $(O)$. Cells were placed in electrical fields for $0.5,1,1.5,2$ or $2.5 \mathrm{~h}$, then the field was turned off for the remainder of the experiment. The polarization of the resulting germ tubes was determined at $7 \mathrm{~h}(\mathrm{O})$. The percentage of yeast cells with germ tubes $(O)$ was determined at the time at which the field was switched off. The error bars are standard errors of the means of triplicate samples, each sample of 100 specimens.

\section{Discussion}

Electrical fields have been shown to polarize the tropic and tactic movements of a range of animal, plant and fungal cells (for a review see Gow, 1987). Some of these cells grow or move towards the cathode, some to the anode and others still to both anode and cathode according to the strength of the field or the culture conditions. These cells mostly generate endogenous electrical fields and currents but there seems to be little correlation between the natural electrical polarity of a cell and the response of the cell to an exogenous electrical field (see discussions in Gow, 1987, 1989b). However the dramatic effects of electrical fields on the polarity of cell growth lends weight to the hypothesis that there is an electrical dimension to the control of cell polarity. For example we report here that neither nucleus nor septum positioning in C. albicans is affected by electrical fields, nor is the general shape of the yeast and hyphal forms. The electrical field effects again seem to be directed rather specifically to the processes that affect the directional growth of the cell.

It is of interest that electrical fields did not lead to the conversion of growth by budding to germ tube growth despite the fact that the germ tube can be regarded as being a highly polarized bud (Staebell \& Soll, 1985; Gow, 1988). Chaffin (1984) showed that buds of $C$. albicans were often formed adjacent to one another for cells grown at $23-28^{\circ} \mathrm{C}$ while site selection was non-adjacent for germ tubes or for buds produced at $37^{\circ} \mathrm{C}$. Our results demonstrate that site selection mechanisms can be made to generate adjacent evaginations for both buds and germ tubes.

In $N$. crassa and other filamentous fungi prolonged growth of germ tubes in an electrical field results in hyphae reorienting from parallel to perpendicular growth in the field (McGillivray \& Gow, 1986). McGillivray \& Gow (1986) reasoned that this reorientation relieved the effects of electrical-field-induced perturbations to the membrane potential, which would be increasingly depolarized at the cathodic end, and hyperpolarized at the anodic end of hyphae extending parallel to an electric field. In contrast, hyphae experience a constant voltage drop when growing perpendicular to the field. Interestingly, germ tubes of $C$. albicans always grew parallel to the field and perpendicular growth was not seen even after extensive growth in strong fields. An explanation for this may relate to differences in the structure of the septum of $C$. albicans and filamentous moulds. Fungi such as $N$. crassa have septa with large pores and the hyphal compartments of the mycelium are electrically continuous. The septum of C. albicans has a membrane-lined micropore which is estimated to have a diameter of $25 \mathrm{~nm}$ (Gow et al., 1980). It has been assumed that this micropore maintains cytoplasmic continuity between adjacent compartments (Gow \& Gooday, 1982). The absence of perpendicular growth in C. albicans suggests however that the hyphae of this organism may not be electrically continuous across septal junctions. Each discrete intercalary compartment would only experience a small increment of the total field. This implies that the septal pore of $C$. albicans has no functional significance. 
The ways in which electrical fields cause tactic and tropic responses are not clear but the mechanisms include causing the electrophoretic redistribution of membrane proteins or cytoplasmic components, the induction of differential uptake of ions such as $\mathrm{Ca}^{2+}$ or $\mathrm{H}^{+}$at the anode- and cathode-facing poles of a cell, and by affecting the architecture of microfilaments or microtubules (Robinson, 1985; Gow, 1987, 1989b,c). We have shown here that an electrical field was only required for a fraction of the time taken for the first germ tubes to form. Thus the effect of exposing a cell to an electrical field was not lost immediately after the field was turned off. The most plausible explanation for this result is that morphogenetic proteins in the membrane become redistributed in the electric field according to their surface charge and that this redistribution is randomized slowly once the field is turned off (Stollberg \& Fraser, 1989).

The response of cells to eleetrical fields of increasing strength differed in the budding and germ-tube-forming modes. For buds a maximum value for the measured polarization occurred at around $12 \mathrm{mV}$ per cell; above this the polarization decreased. For germ tubes the polarization response was biphasic, increasing rapidly for fields up to $5 \mathrm{mV}$ per cell then more slowly in fields that were stronger still. The reason for this difference is not clear but it may indicate significant differences in the proteins or processes which are concerned with bud and germ tube formation. It has been suggested that electrical fields may open and close voltage-sensitive calcium channels and thereby induce asymmetric $\mathrm{Ca}^{2+}$ transport which, in turn, affects tropic and tactic movements (Robinson, 1985; Cooper \& Schliwa, 1986; Onuma \& Hui, 1988). It is conceivable that the sensitivities of voltage-gated proteins such as calcium channels differ in the two growth forms of $C$. albicans at high fields. We are now investigating relationships between calcium transport, galvanotropism and dimorphism.

We thank Debbie Marshall for help with the SEM. This study was supported from a grant from the SERC (GR/E 2943.4).

\section{References}

Buffo, J., Herman, M. A. \& Soll, D. R. (1984). A characterisation of pH-regulated dimorphism in Candida albicans. Mycopathologia 85, 21-30.

COOPER, M. S. \& SCHLIWA, M. (1986). Transmembrane $\mathrm{Ca}^{2+}$ fluxes in the forward and reversed galvanotaxis of fish epidermal cells. In Ionic Currents in Development (Proceedings of a Satellite Meeting to the 10th International Congress of the International Society of Developmental Biologists, University of California, Los Angeles), pp. 311-318. Edited by R. Nuccitelli. New York: Alan R. Liss.

CHAFFIN, W. L. (1984). Site selection for bud and germ tube emergence in Candida albicans. Journal of General Microbiology 130, 431-440.
De Vries, S. C. \& Wessels, J. G. H. (1982). Polarized outgrowth of hyphae by constant electrical fields during reversion of Schizophyllum commune protoplasts. Experimental Mycology 6, 95-98.

Gow, N. A. R. (1984). Transhyphal electrical currents in fungi. Journal of General Microbiology 130, 3313-3318.

Gow, N. A. R. (1987). Polarity and branching in fungi induced by electrical fields. In Spatial Organization in Eukaryotic Microbes (Special Publications of the Society for General Microbiology, vol. 23), pp. 25-41. Edited by R. K. Poole \& A. P. J. Trinci. Oxford: IRL Press.

Gow, N. A. R. (1988). Biochemical and biophysical aspects of dimorphism in Candida albicans. In Proceedings of the 10th Congress for Human and Animal Mycology, pp. 73-77. Edited by J. M. TorresRodriguez. Barcelona: J. R. Prous Science.

Gow, N. A. R. $(1989 a)$. Relationship between growth and the electrical current of fungal hyphae. Biological Bulletin 176S, 31-35.

Gow, N. A. R. (1989b). Circulating ionic currents in microorganisms. Advances in Microbial Physiology 30, 89-123.

Gow, N. A. R. (1989c). Control of the extension of the hyphal apex. Current Topics in Medical Mycology 3, 109-152.

Gow, N. A. R. \& Gooday, G. W. (1982). Growth kinetics and morphology of colonies of the filamentous form of Candida albicans. Journal of General Microbiology 128, 2187-2194.

Gow, N. A. R., Gooday, G. W., Newsam, R. J. \& Gull, K. (1980). Ultrastructure of the septum in Candida albicans. Current Microbiology 4, 357-359.

Gow, N. A. R., Kropf, D. L. \& Harold, F. M. (1984). Growing hyphae of Achlya bisexualis generate a longitudinal $\mathrm{pH}$ gradient in the surrounding medium. Journal of General Microbiology 130, 29672974.

Harold, F. M., Schreurs, W. J., Harold, R. L. \& CaldWell, J. H. (1985). Electrobiology of fungal hyphae. Microbiological Sciences 2, 363-366.

Kropf, D. L., Lupa, M. D. A., Caldwell, J. C. \& Harold, F. M. (1983). Cell polarity: endogenous ion currents precede and predict branching in the water mold Achlya. Science 220, 1385-1387.

LeE, K. L., BUCKLeY, H. R. \& CAMPBeLl, C. C. (1975). An amino acid liquid synthetic medium for the development of mycelial and yeast forms of Candida albicans. Sabouraudia 13, 148-153.

McGillivray, A. M. \& Gow, N. A. R. (1986). Applied electrical fields polarize the growth of mycelial fungi. Journal of General Microbiology $113,2515-2525$.

McGillivray, A. M. \& Gow, N. A. R. (1987). The transhyphal electrical current of Neurospora crassa is carried principally by protons. Journal of General Microbiology 133, 2875-2881.

ONUMA, E. K. \& HUI, S.-W. (1988). Electric field-directed cell shape changes, displacement, and cytoskeletal reorganization are calcium dependent. Journal of Cell Biology 106, 2067-2075.

RoBinson, K. R. (1985). The responses of cells to electrical fields: a review. Journal of Cell Biology 101, 2023-2027.

Schreurs, W. J. A. \& Harold, F. M. (1988). Transcellular proton current in Achlya bisexualis hyphae: relationship to polarized growth. Proceedings of the National Academy of Sciences of the United States of America 85, 1534-1538.

Staebell, M. \& Soll, D. R. (1985). Temporal and spatial differences in cell wall expansion during bud and mycelium formation in Candida albicans. Journal of General Microbiology 131, 1467-1480.

Stollberg, J. \& Fraser, S. E. (1989). Electric field-induced redistribution of $\mathrm{ACh}$ receptors on cultured muscle cells: electromigration, diffusion, and aggregation. Biological Bulletin 176S, 157163.

TAKeuchi, Y., SChmid, J., Caldwell, J. C. \& Harold, F. M. (1988). Transcellular ion currents and extension of Neurospora crassa hyphae. Journal of Membrane Biology 101, 33-41.

ThIEL, R., SChreurs, W. J. A. \& HAROLD, F. M. (1988). Transcellular ion currents during sporangium development in the water mould Achlya bisexualis. Journal of General Microbiology 134, 1089-1097.

VAN LAERE, A. (1988). Effect of electrical fields on polar growth of Phycomyces blakesleeanus. FEMS Microbiology Letters 49, 111-116.

YouatT, J., Gow, N. A. R. \& GoOday, G. W. (1988). Bioelectric and biosynthetic aspects of cell polarity in Allomyces macrogynus. Protoplasma 146, 118-126. 